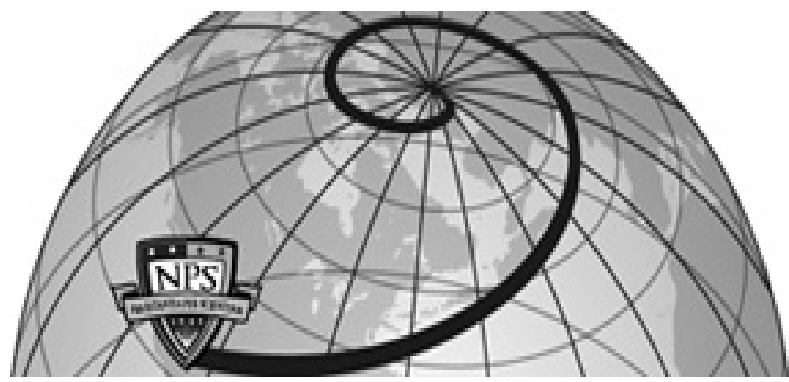

Calhoun: The NPS Institutional Archive DSpace Repository

Why has the Middle East been so Slow to Globalize?

Looney, Robert

Review of Middle East Economics and Finance Vol. 3, No. 3, 173202, December 2005 https://hdl.handle.net/10945/40869

This publication is a work of the U.S. Government as defined in Title 17, United States Code, Section 101. Copyright protection is not available for this work in the United States.

Downloaded from NPS Archive: Calhoun

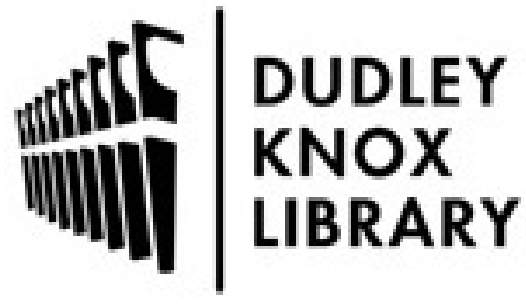

http://www.nps.edu/library
Calhoun is the Naval Postgraduate School's public access digital repository for research materials and institutional publications created by the NPS community. Calhoun is named for Professor of Mathematics Guy K. Calhoun, NPS's first appointed -- and published -- scholarly author.

Dudley Knox Library / Naval Postgraduate School 411 Dyer Road / 1 University Circle Monterey, California USA 93943 


\title{
Why has the Middle East been so Slow to Globalize?
}

\author{
ROBERT LOONEY
}

Naval Postgraduate School

The notion that the poor countries of the world can in any reasonable interval achieve rich-country incomes without trade and capital flows is utterly implausible. If the poor countries of the world have to depend on themselves for the saving to finance the investment that they need, or have to develop themselves the skills and technology they need to become rich by our standards, its going to take forever.-Nobel Laureate Robert Solow

George Seurat created sweeping 'Pointillist' landscapes by painting millions of tiny dots. But that effort is nothing compared with the painstaking detail involved in creating a landscape of economic, political and social reform.-King Abdullah II of Jordan, April 2004

AbSTRACt Over the last several decades, the economic performance of the Middle East and North Africa (MENA) has lagged behind many other parts of the world. While a number of factors have been cited as the cause of the region's malaise, the lack of globalization is increasingly mentioned as a possible source of difficulty. Focusing on the factors responsible for increased levels of globalization, it appears that internal policy reforms rather than external constraints are primarily responsible for the relative integration of the MENA countries into the world economy. Of the areas of policy under the direct control of MENA governments, improvements in several categories of governance, rather than further economic reforms, appear most effective in the attainment of increased levels of globalization.

Key Words: Globalization, Middle East, economic integration JEL Classifications: FO2, F150 


\section{R. Looney}

\section{Introduction}

The gap between the per capita income of most Middle East and North African (MENA) countries and that of advanced industrial countries has widened since the early 1990s. The economic growth performance of the MENA countries has also been weak by developing country standards. Yet the diversity of growth patterns within this group defies easy generalizations on the reasons underlying the disappointing performance (Nunnenkamp, 2004).

One increasingly held view is that many of the economic and social problems confronting most Middle Eastern countries stem from their failure to become more integrated into the global economy. The benefits of globalization are widely documented. As noted in a recent World Bank (2002) report:

Globalization generally reduced poverty because more integrated economies tend to grow faster and this growth is usually widely diffused. As low income countries break into global markets for manufactures and services, poor people can move from the vulnerability of grinding rural poverty to better jobs, often in towns or cities. In addition to the structural relocation, integration raises productivity job by job.

Unfortunately, the term 'globalization' is ill defined and as a result means many different things to different people. In the advanced industrial countries, it is often largely viewed in economic terms - the free movement of goods, services, labor and capital across boarders. Although it does not constitute a new phenomenon, it is often seen as the inexorable integration of markets, nations and technologies to a degree never witnessed before in a way that is enabling individuals, and corporations, to reach around the world further, faster, deeper and more economically than ever before.

In the Middle East North Africa (MENA) region, however, globalization has often been discussed in largely ideological terms. It has been promoted by a few, such as King Abdullah of Jordan, but more often attached as a new version of imperialism. Critics have pointed to a number of related dangers, all of which they see as part of a real of potential threat to their political, economic and cultural independence. One thing is fairly certain, regardless of how one measures it, the MENA region remains one of the most unglobalized regions in the world.

After examining recent patterns of economic integration and addressing the operational issues involved in measuring globalization, the sections below examine the factors underlying the weak integration of the MENA countries into the global economy. Have these been largely in the form of external constraints dictated by forces outside the control of the region as a whole? Or, in contrast, have internal constraints on the nature and speed of reforms in individual countries been responsible? Specifically, have economic reforms been insufficient to take advantage of the opportunities opened up by increased world-wide integration? Or, has the lag in governance and institutional development been primarily responsible? 


\section{MENA in the World Economy}

There is no question the MENA countries as a whole are poorly integrated into the world economy. The region receives only one third the foreign direct investment (FDI) expected for its economic size (and most is concentrated in enclave sectors of a handful of countries, while portfolio investment is virtually nonexistent because equity markets are underdeveloped. As a recent International Monetary Fund study observed (Abed, 2003):

1. Global financial integration lags behind that in other regions; less than half of MENA countries have meaningful access to financial markets. Trade performance is below that of other regions: while oil exports continue to be a substantial source of foreign exchange earnings for oil producers, the relative importance (until the recent price increases) of such exports declined since 1985. The growth of non-oil exports varied during this period but on the whole, was slower than for developing countries as a group.

2. As a result the MENA region's share of the world export market fell by more than half between 1980 and 2000 (the results are the same including or excluding oil exports), whereas the developing countries' share rose slightly during this same period. The region's information and technology links are among the weakest in the world - the number of internet user per capita, for example, is low compared with other regions.

The Middle East region as a whole did as well or better than Latin America and even Asia in the first postwar decades, but has declined steadily for the last thirty years despite the dramatic rise in the price of oil-as its failure to integrate with the world economy has become glaringly obvious (Noland and Pack, 2004). Over the past 20-25 years, most of the region has essentially 'de-globalized' at a time when its population was doubling. A variety of indicators point to this de-globalization (Bergsten, 2004):

- The Middle East share of world trade has dropped by $75 \%$ in the last 25 years;

- Half of the Arab League's 22 members have not even joined the World Trade Organization (WTO);

- The 22 nations of the Arab League, with a population of 260 million, receive half as much FDI as Sweden, with a population of 9 million;

- The ratio of FDI to gross domestic product (GDP) in the Middle East countries is at least three to four times lower than found in other developing economies;

- Tariff rates in the region remain very high - ranging from more than $40 \%$ in Pakistan to $20 \%$ or higher in nations such as Egypt, Syria or Saudi Arabia;

- While regional economic integration has become a top priority throughout Asia, Latin American and even Africa, conflicts, boycotts and sanctions limit the possibility in the Middle East; 
- Foreign equity investment in the entire region roughly equals that of Indonesia, suggesting a very undeveloped capital market and poor allocation of the very limited savings pool it has to draw upon;

- The Middle East countries together spend about half as much per year tapping international technology as does Brazil.

Several studies have attempted to capture and summarize these patterns in some sort of aggregate summary index. For example, the World Bank (1996) has developed a 'Speed of Integration Index' (table 1). The Index was derived from changes between the early 1980s and early 1990s in four main indicators: (1) the ratio of real trade to GDP, (2) the ratio of FDI to GDP, (3) Institutional Investor credit ratings, and the share of manufactures. The speed of integration index is the simple average of changes in the four indicators over the period expressed as standardized scores.

The index confirms the fact that MENA countries have been slow to integrate into the world economy. Compared with other regions, MENA has a high proportion of 'weak' and 'slow' integrators. Nearly $67 \%$ of the countries in East Asia are considered 'fast' integrators as are $23 \%$ of those in Latin America and the Caribbean. In contrast, only $15 \%$ of MENA countries can be classified as such. Significantly, the percentage $(38.4 \%)$ of MENA countries that are 'slow integrators', is only marginally lower than similar ones in sub-Saharan Africa (39\%), but significantly higher than those in Latin America and the Caribbean.

Taking a slightly different approach, a recent composite index (Looney and Frederiksen, 2004) of world-wide movements in globalization found the Middle Eastern countries falling further behind other parts of the world in their degree of integration into the world economy. South Asia along with the Middle East has experienced a distinct downward trend over this period (figure 1). That is even though these countries may have introduced liberalization programs, deregulation of key sectors, and more open trade regimes, becoming more globalized in an absolute sense, they fell behind the advanced countries and East Asian countries in a relative sense.

\section{Approaches in Defining Globalization}

As the previous section suggests, there are many ways in which the MENA region interacts with the rest of the world. Are some indicators more significant indicators than others? Clearly, when examining globalization patterns and issues, one of the first issues is to define exactly what one is talking about (Dunn, 2001). As noted above, there are a myriad of ways of viewing and measuring globalization. However, three approaches stand out.

First, globalization can be seen as the growing liberalization of international trade and investment that results in increases in the integration of national economies (Griswold, 2000). Henderson (1999) has expanded this definition to define globalization as consisting of five related but distinct parts:

- The increasing tendency for firms to think, plan, operate and invest for the future with reference to markets and opportunities across the world as a while. 
Table 1. Speed of integration of developing countries, early 1980s to early 1990 s

\begin{tabular}{|c|c|c|c|c|c|c|c|c|c|c|c|c|}
\hline \multirow{2}{*}{ Speed } & \multicolumn{2}{|c|}{ East Asia } & \multicolumn{2}{|c|}{ South Asia } & \multicolumn{2}{|c|}{$\begin{array}{c}\text { Latin America \& } \\
\text { Caribbean }\end{array}$} & \multicolumn{2}{|c|}{$\begin{array}{l}\text { Middle East \& } \\
\text { North Africa }\end{array}$} & \multicolumn{2}{|c|}{$\begin{array}{c}\text { Sub-Saharan } \\
\text { Africa }\end{array}$} & \multicolumn{2}{|c|}{$\begin{array}{c}\text { Europe \& } \\
\text { Central Asia }\end{array}$} \\
\hline & No. & $\%$ & No. & $\%$ & No. & $\%$ & No. & $\%$ & No. & $\%$ & No. & $\%$ \\
\hline Fast Integrators & 6 & 66.7 & 3 & 60.0 & 5 & 23.8 & 2 & 15.4 & 2 & 5.5 & 5 & 55.6 \\
\hline Moderate Integrators & & & 2 & 40.0 & 5 & 23.8 & 4 & 30.8 & 10 & 27.8 & 2 & 22.2 \\
\hline Weak Integrators & 3 & 33.3 & & & 9 & 42.9 & 2 & 15.4 & 10 & 27.8 & & \\
\hline Slow Integrators & & & & & 2 & 9.5 & 5 & 38.4 & 14 & 38.9 & 2 & 22.2 \\
\hline Total & 9 & 100.0 & 5 & 100.0 & 21 & 100.0 & 13 & 100.0 & 36 & 100.0 & 9 & 100.0 \\
\hline
\end{tabular}

Source: Global Economic Prospects and the Developing Countries (Chapter 2, Box 1) (Washington DC: World Bank, 1996). 


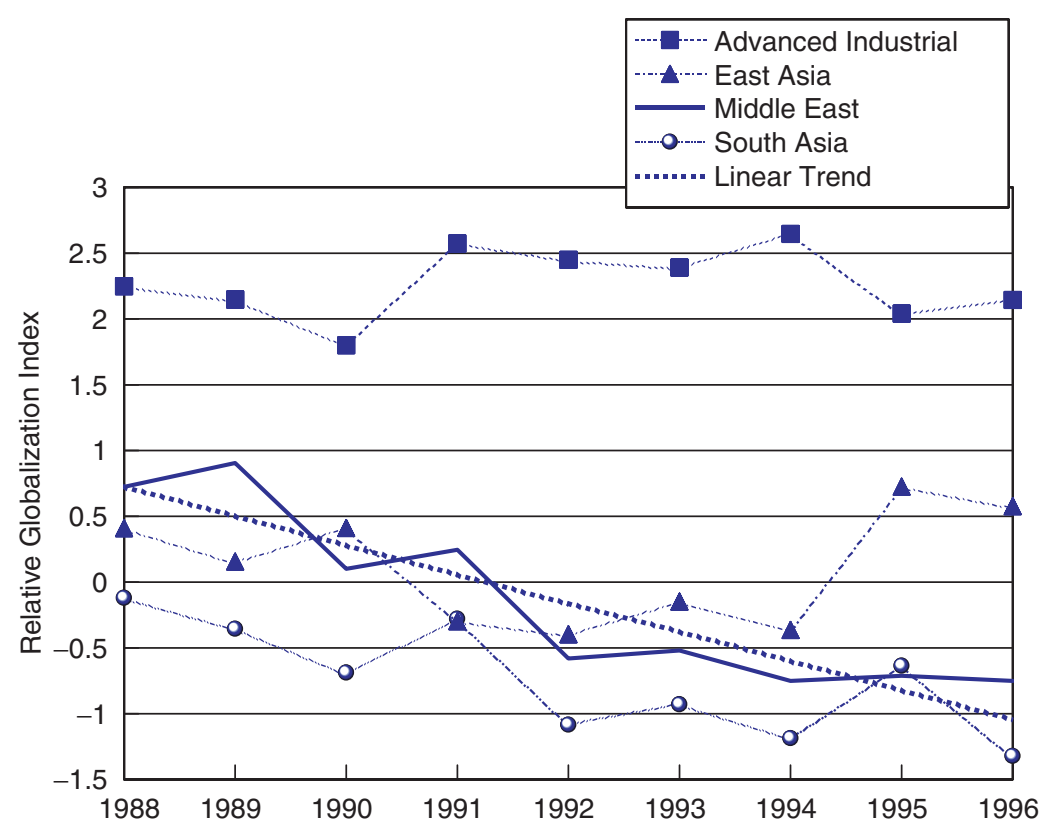

Figure 1. Patterns of globalization, 1988-1996 (Source: Looney and Frederiksen, 2004).

- The growing ease and cheapness of international communications, with the Internet as the leading aspect.

- The trend towards closer international economic integration, resulting in the diminished importance of political boundaries. This trend is fueled partly by the first two trends, but even more powerfully by official policies aimed at trade and investment liberalization.

- The apparently growing significance of issues and problems extending beyond national boundaries and the resulting impetus to deal with tem through some form of internationally concerted action.

- The tendency towards uniformity (or harmonization by which norms, standards, rules and practices are defined and enforced with respect to regions or the world as a whole rather than within the bounds of national states.

A second way of viewing globalization is from the manner in which it is perceived by different governments/groups. Here, views about globalization can be categorized into four main perspectives: (1) economic, (2) technological, (3) development, and (4) societal (Mujahid, 2002).

The Economic Perspective of globalization focuses on the growth of world trade as a proportion of output (the ratio of world imports to gross world product has grown from some $7 \%$ in 1938 to about $10 \%$ in 1970 to over $20 \%$ in 2000). It is reflected in the explosion of FDI: FDI in developing countries has increased from US\$2.2 billion in 1970 to nearly US\$200 billion in 2000 . It has resulted also in national capital markets becoming increasingly integrated, to the point where some US\$1.3 trillion per day crosses the foreign exchange 
markets of the world, of which less than $2 \%$ is directly attributable to trade transactions.

The Technological Perspective of globalization stresses the importance of new technologies in the communication and transport sectors. As a result of these technological advances the costs of transport, of travel, and above all the costs of communicating information have fallen dramatically in the postwar period. For example, a 3-minute telephone call from the USA to Britain cost US\$12 in 1946, whereas today it can cost as little as 48 cents, despite the fact that consumer prices have multiplied by over eight times in the intervening period. As a result of new technologies and lower costs, multinationals have been able to switch operations to cheaper developing countries. Companies like Dell have been outsourcing in India for tasks such as customer service. To a much lesser extent a MENA country, Pakistan, has also been a beneficiary of this sort of out-sourcing. Another dimension to this phenomena is the brain drain of highly skilled workers from India and Pakistan to the USA and Europe. Remittances from these workers are becoming a major source of foreign exchange for these countries.

The Development Perspective of globalization is the most controversial. Has globalization done one or all of the following: (a) lessened or increased the gap between the rich countries and the poorer? (b) caused increased poverty and income disparity in countries more exposed to world market forces? and (c) expanded the gap between the technological haves and have-nots? Unfortunately, economic theory provides no definitive answer with neoclassical advocates ${ }^{1}$ stressing the convergence of incomes, while exogenous growth theorists acknowledging that divergence might be underway (Romer, 1986; Lucas 1988). A related debate takes off from the old spread and backwash models of development (Landes, 1998).

The Societal Perspective of globalization focuses on some key factors that the globalization process is associated with or is said to impact. These include the condition of human rights, women empowerment, gender sensitization, civic education, status of women in the society, political status becoming more democratic, freedom of speech, rule of law, equal access to resources and level of education.

A third and final way of examining globalization is to view it has a historical process. This approach is best summarized by Nobel Prize winner Amartya Sen (2001) of Cambridge University:

1. Globalization is not new, nor is it just Westernization: Over thousands of years, globalization has progressed through travel, trade, migration, spread of cultural influences and dissemination of knowledge and understanding (including since and technology).

2. Globalization is not in itself a folly: It has enriched the world scientifically and culturally and benefited many people economically as well. In this regard modern technologies as well as economic interrelations have been influential.

3. The use of the market economy can produce different outcomes. Specifically, the market economy can generate many different results, 
depending on how physical resources are distributed, how human resources are developed, what rules prevail and so on in all these spheres and the state and the society have roles, within a country and in the world.

4. The world has changed since the Bretton Woods Agreement: The current economic, financial, and political architecture of the world (including the World Bank, the International Monetary Fund and other institutions) was largely set up in the 1940s, following the Bretton Woods Conference in 1944. The implication being that the current system does not have institutions that are responsive to many of the changed economic circumstances and as such many parts of the world are not well served by the current system.

Sen is suggesting that various parts of the world have evolved somewhat differently over the last several decades and, as a result, possess economic environments that have different potentials for: (1) growth, (2) technological absorption, and (3) responding to external shocks. Of the approaches to globalization noted above, this one appears to be the most useful for the purposes at hand. To be useful, however, one must first derive an operational, quantifiable classification of these environments, and then show how they have varied over time.

\section{Approaches at Measuring Globalization}

The different approaches to examining globalization while providing valuable insights to the phenomena also illustrate the problems confronting researchers in the area. Globalization is a complex, multi-dimensional, historical process that does not lend itself easily characterization or measurement. In fact, despite the volumes written on globalization, relatively little progress has been devoted to coming up with a generally accepted measure of the concept. Has globalization progressed more in Turkey than Egypt and if so by how much and in what respect? Or as noted by the A.T. Kearny Corporation (2002):

For instance, how do we determine the extent to which a country has become embedded within the global economy? How do we demonstrate that globalization is racing ahead, rather than just limping along? Clearly, the lack of a clear, precise definition underlies much of the current arguments and debates overmuch the extent of globalization and the manner that phenomenon is changing the structure of national economies. Without the means to quantify the extent of globalization, any meaningful evolution of its effects will remain elusive.

The few attempts made at quantifying globalization are often little more than rankings of countries according to various criteria, such as the share of trade in GDP, or the percentage of investment accounted for by FDI. Such comparisons may be informative, but they suffer from arbitrariness in the selection of data. More fundamentally, since countries usually rank differently 
depending on the data series selected, how should these series be combined to form an unambiguous summary metric of globalization?

An attempt to overcome these problems has been made in the annual A.T. Kearney/Foreign Policy Magazine (KFP) Globalization Index. ${ }^{2}$ This aggregate index includes over 60 countries and is derived from measures of four main dimensions of globalization: (1) technology (number of internet users, internet hosts, and secure severs), (2) political engagement (number of memberships in international organization, UN security council missions in which each country participates and foreign embassies that each country hosts), (3) personal contact (international travel and tourism, international telephone traffic, and cross-border transferees) and (4) economic integration (trade, FDIs and portfolio capital flows and income payments and receipts). The four dimensions are then aggregated into an overall summary measure of globalization (Andersen and Herbertsson, 2003).

While the KFP index represents a breakthrough in conceptualizing the globalization process, it is not without its critics. As with any index of this sort, it contains a certain element of arbitrariness: ${ }^{3}$ (1) Are the measures included in the index better than any other conceivable set? (2) Is the weighting system more meaningful than other possibilities? (3) Should efforts be made to correct for the size of countries? - if Yemen does not host as many foreign embassies as the USA is it somehow less globalized? - the KFP index would say yes.

As expected, the KFP globalization index (table 2) shows the Middle Eastern countries clustered towards the bottom. Out of the 62 countries covered, the region's most globalized country in 2002 was Israel (22). Tunisia (35) is the only other Middle Eastern country in the top 40.

Several features of the index are also of interest. First, there seems to be great year-to-year variation. Morocco's ranking fell 18 notches between 2002 and 2001 while Egypt's fell by 12. Ruling out some sort of calamity (natural or financial), this is not something one would expect in the real world. Second, country rankings vary considerably across the different dimensions of globalization. The USA ranks first on the technological dimension, but 56th on the economic dimension. Third, some of the rankings seem counterintuitive. One would not expect the USA (at 56th on the economic dimension) to be less globalized than Pakistan (at 55th). Is Tunisia at 35th really more globalized than Taiwan at 36th? Common sense says no.

Several of these anomalies can be eliminated by smoothing over the KFP Index through the use of Factor Analysis. ${ }^{4}$ Clearly the four KFP dimensions of globalization are not independent of each other, and a factor analysis of them can test to determine the extent to which they are correlated to another (unmeasured) dimension that we might dub 'General Globalization'. In turn each country can be ranked in terms of its attainment on this 'General Globalization' dimension.

The results of this smoothing exercise (table 3 ) suggest a possible alternative to the KFP Policy index. The KFP summary index (0.815), the technical dimension of globalization (0.924) as well as the personal (0.660) and economic dimension (0.586) are all fairly highly correlated with this General Globalization measure. Only the political dimension seems to stand alone 
Table 2. Kearney/Foreign Policy Globalization Index, 2004

\begin{tabular}{|c|c|c|c|c|c|c|}
\hline \multirow[b]{2}{*}{$\begin{array}{l}2004 \\
\text { Ranking }\end{array}$} & \multirow[b]{2}{*}{ Country } & \multirow[b]{2}{*}{$\begin{array}{l}\text { Change } \\
\text { from } 2003\end{array}$} & \multicolumn{4}{|c|}{ Globalization dimension } \\
\hline & & & Economic & Personal & Technological & Political \\
\hline 1 & Ireland & 0 & 1 & 2 & 14 & 11 \\
\hline 2 & Singapore & 2 & 2 & 3 & 10 & 40 \\
\hline 3 & Switzerland & -1 & 9 & 1 & 7 & 33 \\
\hline 4 & Netherlands & 1 & 3 & 11 & 8 & 14 \\
\hline 5 & Finland & 5 & 7 & 15 & 4 & 12 \\
\hline 6 & Canada & 1 & 18 & 5 & 3 & 20 \\
\hline 7 & United States & 4 & 56 & 35 & 1 & 28 \\
\hline 8 & New Zealand & 8 & 35 & 10 & 2 & 3 \\
\hline 9 & Austria & -1 & 13 & 6 & 13 & 1 \\
\hline 10 & Denmark & -4 & 12 & 8 & 6 & 10 \\
\hline 22 & Israel & -3 & 31 & 7 & 19 & 44 \\
\hline 35 & Tunisia & 4 & 25 & 31 & 46 & 42 \\
\hline 41 & Saudi Arabia & 0 & 49 & 24 & 43 & 59 \\
\hline 46 & Pakistan & 6 & 55 & 36 & 59 & 34 \\
\hline 47 & Morocco & -18 & 54 & 30 & 54 & 55 \\
\hline 55 & Turkey & -8 & 53 & 49 & 38 & 52 \\
\hline 60 & Egypt & -12 & 58 & 47 & 53 & 49 \\
\hline 62 & Iran & 0 & 59 & 62 & 48 & 61 \\
\hline
\end{tabular}

and represent a somewhat independent aspect of globalization. Using this new General Globalization scale, the ranking of countries changes somewhat. The USA is now ranked 2nd rather than 7 th, while Taiwan is ranked 6th rather than 36th. These changes seem more realistic than the original KFP rankings.

On the other hand, the picture for many other countries is more or less the same-Morocco is now 46th rather than 47th, Egypt is 54th rather than 60th and so on. More importantly, the new rankings illustrate the fundamental problem of globalization indexes. Ultimately, all are arbitrary.

Despite these limitations the KFP index incorporates measures of performance stemming from forces a growing consensus of observers feel have contributed to the expansion of globalization in recent decades (Intriligator, 2003):

- Technological innovation has significantly lowered the costs of transportation and communication, while driving down the costs of data processing and storage.

- Trade liberalization and other factors of economic liberalization have contributed greatly to the interchange between nations. These processes started in the 19th century, but the two world wars and the Great Depression interrupted them. The processes resumed after World War II, embodied in the 1946 General Agreement of Tariffs and Trade, which has since evolved into the World Trade Organization. Barriers to trade in goods and services are down sharply while movements of capital, labor and technology face fewer obstacles. 
Table 3. Factor analysis of the Kearney globalization data set

\begin{tabular}{|c|c|c|c|c|}
\hline Variables & $\begin{array}{c}\text { Factor } 1 \\
\text { General } \\
\text { globalization }\end{array}$ & $\begin{array}{c}\text { Factor } 2 \\
\text { Political } \\
\text { dimension }\end{array}$ & $\begin{array}{l}\text { Factor } 3 \\
\text { Economic } \\
\text { dimension }\end{array}$ & $\begin{array}{c}\text { Factor } 4 \\
\text { Transfer } \\
\text { dimension }\end{array}$ \\
\hline Technical dimension & 0.924 & 0.223 & 0.152 & - \\
\hline Internet users & 0.912 & 0.196 & 0.104 & - \\
\hline Secure servers & 0.912 & 0.255 & 0.138 & - \\
\hline Internet hosts & 0.911 & 0.263 & 0.102 & - \\
\hline Telephone & 0.886 & 0.200 & 0.181 & 0.236 \\
\hline Summary ranking & 0.815 & 0.301 & 0.322 & 0.281 \\
\hline Travel & 0.755 & 0.145 & 0.290 & 0.367 \\
\hline Portfolio & 0.696 & 0.275 & 0.305 & \\
\hline Personal dimension & 0.660 & 0.149 & 0.204 & 0.651 \\
\hline Investment Income & 0.599 & 0.206 & 0.536 & \\
\hline Political dimension & 0.329 & 0.845 & 0.334 & 0.134 \\
\hline International organizations & 0.305 & 0.723 & - & -0.160 \\
\hline UN peacekeaping & 0.421 & 0.710 & & \\
\hline Treaties & -0.117 & 0.445 & 0.750 & \\
\hline Economic dimension & 0.586 & - & 0.731 & 0.255 \\
\hline FDI & 0.493 & - & 0.681 & \\
\hline Trade & 0.363 & -0.431 & 0.497 & 0.476 \\
\hline REMIT04 & -0.217 & -0.164 & - & 0.888 \\
\hline GTRANS04 & 0.216 & 0.538 & 0.191 & 0.607 \\
\hline Country & $\begin{array}{l}\text { Factor score } \\
\text { ranking }\end{array}$ & $\begin{array}{l}\text { Kearney } \\
\text { ranking }\end{array}$ & \multicolumn{2}{|c|}{$\begin{array}{l}\text { General globalization } \\
\text { factor score }\end{array}$} \\
\hline Singapore & 1 & 2 & \multicolumn{2}{|c|}{-2.09425} \\
\hline United States & 2 & 7 & \multicolumn{2}{|c|}{-1.75985} \\
\hline Switzerland & 3 & 3 & \multicolumn{2}{|c|}{-1.63928} \\
\hline Netherlands & 4 & 4 & \multicolumn{2}{|c|}{-1.62819} \\
\hline Canada & 5 & 6 & \multicolumn{2}{|c|}{-1.62324} \\
\hline Taiwan & 6 & 36 & \multicolumn{2}{|c|}{-1.50591} \\
\hline Finland & 7 & 5 & \multicolumn{2}{|c|}{-1.44038} \\
\hline Australia & 8 & 13 & \multicolumn{2}{|c|}{-1.25204} \\
\hline Israel & 9 & 22 & \multicolumn{2}{|c|}{-1.15699} \\
\hline New Zealand & 10 & 8 & \multicolumn{2}{|c|}{-1.18089} \\
\hline Saudi Arabia & 32 & 41 & \multicolumn{2}{|c|}{-0.01309} \\
\hline Turkey & 33 & 55 & \multicolumn{2}{|c|}{0.07891} \\
\hline Tunisia & 41 & 35 & \multicolumn{2}{|c|}{0.56558} \\
\hline Morocco & 46 & 47 & \multicolumn{2}{|c|}{0.70648} \\
\hline Iran & 48 & 62 & \multicolumn{2}{|c|}{0.75165} \\
\hline Egypt & 54 & 60 & \multicolumn{2}{|c|}{1.06942} \\
\hline Pakistan & 57 & 46 & \multicolumn{2}{|c|}{1.43823} \\
\hline
\end{tabular}

Source: Compiled by author.

- Changes in institutions and organizations, brought about by advances in transportation and communications. Firms that once focused on regional markets now produce in many countries and sell to the whole world. Indeed almost a third of international trade now occurs within multinational enterprises. 
- A growing consensus on the value of free markets has had a profound effect on economic policies. This process began with the post-Mao reforms in China followed by the collapse of the Soviet system. The division between market economies in the West and command economies in the East has been replaced by a near universal reliance on markets.

These factors suggest that indigenous as well as exogenous factors have been responsible for the limited nature of economic globalization in the MENA region. While a number of recent studies have examined the outside factors prompting international investors to be leery of these states, the internal barriers to globalization have remained largely unexplored (Kamrava, 2004). These are explored below within the framework of the region's reform efforts.

\section{Internal Barriers to Globalization}

For the most part previous studies linking indigenous impediments to globalization in the MENA region have tended to link region's comparatively low levels of global economic integration to any combination of: ${ }^{5}$ (1) insufficiently developed local markets, (2) an underdeveloped or non-existent local labor force (as in the small monarchies of the Persian Gulf), (3) inadequate and inaccessible information technologies, and (4) defensive reactions by local leaders to the perceived sociocultural and political threats of globalization 6 (Kamrava, 2004).

The relative progress made in the various areas of reform provides a useful framework for integrating these factors into a coherent indigenous oriented approach to understanding the globalization process in the MENA region. These fall into two broad categories: (a) those intended to develop efficient market-based economies, with increased economic freedom, and (b) those related to democracy and improved governance.

\section{Economic Freedom}

Both the Heritage Foundation/Wall Street Journal's Index of Economic Freedom ${ }^{6}$ and the Fraser Institute's Economic Freedom of the World ${ }^{7}$ provide good measures of the relative progress made by countries in moving to a deregulated, limited government, free-market environment. Because the Heritage Foundation data set included more of the MENA countries ${ }^{8}$ it was used for the analysis that follows. The Heritage Index reflects the absence of government constraint or coercion on the production, distribution or consumption of goods and services. Stripped to its essentials, economic freedom is concerned with property rights and choice. To measure economic freedom the Heritage Foundation/Wall Street Journal Index takes ten different factors into account:

1. Trade policy;

2. Fiscal burden of government;

3. Government intervention in the economy;

4. Monetary policy; 
5. Banking and finance;

6. Capital flows and foreign investment;

7. Wages and prices;

8. Property rights;

9. Regulation;

10. Informal market.

Implied in these measures is the notion that economic freedom also requires governments to refrain from many activities. They must refrain from actions that interfere with personal choice, voluntary exchange, and the freedom to enter and compete in labor and product markets. Economic freedom is reduced when taxes, government expenditures, and regulations are substituted for personal choice, voluntary exchange and market coordination. Restrictions that limit entry into occupations and business activities also retard economic freedom.

The index provides a framework for understanding most of the objectives of US reform efforts in the region: how open countries are to competition; the degree of state intervention in the economy, whether through taxation, spending or overregulation, and the strength and independence of a country's judiciary to enforce rules and protect private property. Some countries may have freedom in all factors; others may have freedom in just a few. One of the most important findings of research carried out using the index is that economic freedom is required in all aspects of economic life. That is countries must score well in all ten of the factors in order to improve their economic efficiency and consequently the living standards of their people (Eiras, 2003).

\section{Governance}

The other main area of US reform efforts, democracy and governance are increasingly seen as essential for long run economic growth and prosperity. In fact some dimensions of governance now sit at the center of academic and policy discussions of economic development (Kitschelt, 2004).

While the ranking of countries on the basis of their relative progress in attaining improved governance is inherently subjective, a recent World Bank study (Kaufman et al., 2003) provides a set of rankings incorporating the full extent of our knowledge about this phenomenon. More precisely, the World Bank data set presents a set of estimates of six dimensions of governance covering 199 countries and territories for 1996, 1998, 2000 and 2002.

Voice and accountability. This variable measures various aspects of the political process, civil liberties and political rights. These indicators measure the extent to which the citizens of a country are able to participate in the selection of governments. Also included in this variable are indicators measuring the independence of the media.

Political stability and absence of violence. This governance cluster combines several indicators that measure perceptions of the likelihood that the government in power will be destabilized or overthrown. 
Government effectiveness. This variable combines aspects of the quality of public service provision, the quality of the bureaucracy, the competence of civil servants, the independence of the civil service from political pressures, and the credibility of the government's commitment to policies.

Regulatory quality. This aspect of governance is more focused on the policies themselves. It includes measures of the incidence of market-unfriendly policies such as price controls or inadequate bank supervision as well as perceptions of the burdens imposed by excessive regulation in areas such as foreign trade and business development.

Rule of law. Included in this dimension of governance are several indicators that measure the extent to which the citizens of a country have confidence in and abide by the rules of society. These include perceptions of the incidence of crime, the effectiveness and predictability of the judiciary, and the enforceability of contracts.

Control of corruption. This dimension of governance measures perceptions of corruption. By this measure corruption is defined as the exercise of public power for private gain. It is often a manifestation of a lack of respect of both the corrupter and the corrupted for the rules that govern their interactions, and hence represents a failure of governance.

A simple comparison (table 4) of MENA and non-MENA countries suggests the MENA region lags considerably behind other parts of the world in most areas of liberalization. The gap is particularly large in most areas of governance (in table 2 larger values indicate better governance) especially the critical one of voice and accountability. Regulatory quality is another area where the MENA countries significantly lag behind other parts of the world.

On the other hand the MENA countries compare fairly favorably to nonMENA countries in several areas of economic freedom (in table 4 large values indicate lower levels of economic freedom) - monetary policy, fiscal burden and the size of the informal (black) market. Still, the region's trade policies, government intervention, foreign investment, and flexibility in wages and prices lag considerably behind other parts of the world.

To determine if these reform measures were sufficient to separate in some statistical sense the MENA from the non-MENA developing countries, a discriminant analysis was performed. ${ }^{9}$ Of the 22 MENA countries that comparable data was available, 19 were correctly paced in the MENA group (table 5). Fifteen of the MENA countries had a probability of over $90 \%$ as fitting the MENA reform profile. Based on their values of reform attainment, only three countries, Somalia, Sudan and Yemen were classified as likely to be non-MENA developing countries.

The reform variables statistically significant in separating the MENA from non-MENA economies were, in order of importance: (1) government intervention, (2) voice/accountability, (3) rule of law, (4) foreign investment, 
Table 4. Relative reform progress: MENA-non-MENA countries

\begin{tabular}{|c|c|c|c|c|c|c|}
\hline & Voice & $\begin{array}{l}\text { Political } \\
\text { stability }\end{array}$ & $\begin{array}{l}\text { Government } \\
\text { effectiveness }\end{array}$ & $\begin{array}{l}\text { Regulatory } \\
\text { quality }\end{array}$ & $\begin{array}{l}\text { Rule of } \\
\text { law }\end{array}$ & $\begin{array}{l}\text { Control of } \\
\text { corruption }\end{array}$ \\
\hline \multicolumn{7}{|l|}{ Average values $1996-8$} \\
\hline Non-MENA countries (139) & 0.08598 & 0.08841 & 0.05773 & 0.12319 & 0.06515 & 0.04490 \\
\hline MENA countries $(23)$ & -0.97011 & -0.52158 & -0.34716 & -0.52671 & -0.16044 & -0.29197 \\
\hline Difference & 1.05609 & 0.60999 & 0.40489 & 0.6499 & 0.22559 & 0.33687 \\
\hline \multicolumn{7}{|l|}{ Average Values 2000-2 } \\
\hline Non-MENA countries (139) & 0.08478 & 0.04330 & 0.06737 & 0.12383 & 0.04320 & 0.03408 \\
\hline \multirow[t]{2}{*}{ Difference } & 1.06354 & 0.46100 & 0.36715 & 0.62757 & 0.26583 & 0.28330 \\
\hline & $\begin{array}{l}\text { Trade } \\
\text { policy }\end{array}$ & $\begin{array}{c}\text { Fiscal } \\
\text { burden }\end{array}$ & $\begin{array}{l}\text { Government } \\
\text { intervention }\end{array}$ & $\begin{array}{l}\text { Monetary } \\
\text { policy }\end{array}$ & $\begin{array}{c}\text { Foreign } \\
\text { investment }\end{array}$ & \\
\hline \multicolumn{7}{|l|}{ Average values $1995-9$} \\
\hline Non-MENA Countries (136) & 3.54277 & 3.38744 & 2.67261 & 3.37610 & 2.72022 & \\
\hline MENA Countries (22) & 4.14545 & 3.67159 & 3.63788 & 3.01136 & 3.32955 & \\
\hline Difference & -0.60268 & -0.28415 & -0.96527 & 0.36474 & -0.60933 & \\
\hline Non-MENA Countries (137) & 3.32092 & 3.45668 & 2.62786 & 2.49878 & 2.75474 & \\
\hline MENA Countries (22) & 4.04545 & 3.49273 & 3.52273 & 2.14545 & 3.29091 & \\
\hline \multirow[t]{2}{*}{ Difference } & -0.72453 & -0.03605 & -0.89487 & 0.35333 & -0.53617 & \\
\hline & $\begin{array}{l}\text { Banking \& } \\
\text { finance }\end{array}$ & $\begin{array}{l}\text { Wages \& } \\
\text { prices }\end{array}$ & $\begin{array}{l}\text { Property } \\
\text { rights }\end{array}$ & Regulation & $\begin{array}{l}\text { Informal } \\
\text { market }\end{array}$ & \\
\hline \multicolumn{7}{|l|}{ Average Values 1995-9 } \\
\hline Non-MENA Countries (140) & 2.97500 & 2.82488 & 2.76544 & 3.34718 & 3.44265 & \\
\hline MENA Countries (20) & 3.50909 & 3.27500 & 3.06591 & 3.26136 & 3.45455 & \\
\hline
\end{tabular}


Table 4. Continued

\begin{tabular}{|c|c|c|c|c|c|}
\hline & $\begin{array}{l}\text { Banking \& } \\
\text { finance }\end{array}$ & $\begin{array}{l}\text { Wages \& } \\
\text { prices }\end{array}$ & $\begin{array}{l}\text { Property } \\
\text { rights }\end{array}$ & Regulation & $\begin{array}{l}\text { Informal } \\
\text { market }\end{array}$ \\
\hline $\begin{array}{l}\text { Difference } \\
\text { Average values 2000-2 }\end{array}$ & -0.53409 & -0.45012 & -0.30047 & 0.08582 & -0.01190 \\
\hline Non-MENA Countries (139) & 2.88759 & 2.69015 & 2.94526 & 3.43443 & 3.42007 \\
\hline MENA Countries (20) & 3.54545 & 3.14545 & 3.47273 & 3.61515 & 3.56364 \\
\hline Difference & -0.65786 & -0.45530 & -0.52747 & -0.18072 & -0.14357 \\
\hline
\end{tabular}

Compiled from: Daniel Kaufmann, Aart Kraay and Massimo Mastruzzi, Governance Matters III: Governance Indicators for 1996-2002 (Washington, DC: World Bank, 30 June 2003), and Index of Economic Freedom Rankings (Washington, DC: Heritage Foundation), various issues. 
Table 5. Classification of MENA, non-MENA Develoing Countries 2000-2002

\begin{tabular}{|c|c|c|c|}
\hline \multirow[b]{2}{*}{ Country } & \multirow{2}{*}{$\begin{array}{l}\text { Discriminant } \\
\text { score }\end{array}$} & \multicolumn{2}{|c|}{ Group probability } \\
\hline & & Non-MENA & MENA \\
\hline \multicolumn{4}{|c|}{ Very High Probability of MENA Group } \\
\hline Algeria & 1.93978 & 0.06028 & 0.93972 \\
\hline Bahrein & 3.30283 & 0.00232 & 0.99768 \\
\hline Egypt & 1.85825 & 0.07255 & 0.92745 \\
\hline Iraq & 1.91416 & 0.06391 & 0.93609 \\
\hline Jordan & 2.38860 & 0.02106 & 0.97894 \\
\hline Kuwait & 2.08439 & 0.04317 & 0.95683 \\
\hline Libya & 2.44436 & 0.01844 & 0.98156 \\
\hline Morocco & 1.96336 & 0.05711 & 0.94289 \\
\hline Oman & 3.85419 & 0.00061 & 0.99939 \\
\hline Qatar & 4.03015 & 0.00040 & 0.99960 \\
\hline Saudi Arabia & 4.06767 & 0.00036 & 0.99964 \\
\hline Syria & 2.76377 & 0.00856 & 0.99144 \\
\hline Tunisia & 2.65033 & 0.01125 & 0.98875 \\
\hline UAE & 2.90754 & 0.00605 & 0.99395 \\
\hline \multicolumn{4}{|c|}{ High Probability of MENA Group } \\
\hline Iran & 1.65104 & 0.11468 & 0.88532 \\
\hline Pakistan & 1.80163 & 0.08239 & 0.91761 \\
\hline \multicolumn{4}{|c|}{ Moderate Probability of MENA Group } \\
\hline Djibouti & 1.17052 & 0.29435 & 0.70565 \\
\hline Lebanon & 0.81807 & 0.49587 & 0.50413 \\
\hline Mauritania & 1.04407 & 0.36203 & 0.63797 \\
\hline \multicolumn{4}{|l|}{ Miss-Classified } \\
\hline Somalia & 0.63109 & 0.60792 & 0.39208 \\
\hline Sudan & -0.23931 & 0.92804 & 0.07196 \\
\hline Yemen & -0.42607 & 0.95309 & 0.04691 \\
\hline
\end{tabular}

Source: Compiled by author.

Notes: Discriminating variables in order of importance: (1) government intervention, (2) voice/ accountability, (3) rule of law, (4) foreign investment, and (5) property rights.

and (5) property rights. All of these variables are likely to affect or be reflections of actions likely to impact on the globalization process.

The sections below examine the factors underlying the weak integration of the MENA countries into the global economy. In particular have economic reforms been insufficient to take advantage of the opportunities opened up by the factors noted above? Or has the lag in governance and institutional development been primarily responsible?

\section{Globalization and Reforms}

Despite its limitations, the KFP globalization index is still the best tool available for identifying many key relationships of interest to policy makers. If their objective is to increase their integration into the world economy, should the Middle Eastern countries focus on economic reforms 
or improved governance? Or, are both types of reforms of relatively equal importance? Are some reforms more effective in the economic area while others best for improving the technological aspect of globalization?

\section{The Kearney/Foreign Policy (KFP) Summary Measure of Globalization}

Splitting the KFP over-all ranking of countries into two groups-the top 31 countries or highly globalized economies and the bottom 31 countries or, lesser globalized countries produces several patterns. First significant differences in governance exist between the two groups of countries (table 6). On all of the major dimensions of governance, the top group has made significantly more progress in most areas of reform. The greatest gap between the two groups appears to be in the control of corruption followed by the rule of law and government effectiveness.

While the high globalizers also outperform the low globalizers in most of the economic areas (high values in the economic areas indicate a lower level of attainment), the differences between the two do not appear nearly as large as in the governance measures. In fact, as was the case with the MENA and nonMENA groupings, the low globalizers have lower fiscal burdens than their high globalizer counterparts. In the economic area the high globalizers have the biggest lead in eliminating the informal (black) markets, developing sound banking and finance sectors and in implementing good trade policy (openness).

To gain a rough idea of the reform/globalization linkages for the MENA countries another discriminant analyis was carried out. Based on their KFP overall Globalization rank, countries were split into two groups - a high degree of globalization group with ranks from 1 to 31 , and a low globalization group with ranks from 32 to 62 . Using the governance and economic freedom variables to classify the high and low globalized nations, $91.9 \%$ of the $62 \mathrm{KFP}$ countries were correctly classified (table 7). All of the MENA countries, together with Israel and Turkey were correctly classified. As anticipated from the previous examination of reform variable means, the classification of high and low globalized countries was dominated by governance variables.

In order of statistical importance the statistically significant, classifying variables were: (1) rule of law, (2) voice and accountability, (3) property rights and (4) regulatory quality. A similar result was obtained using the composite Factor Score ranking of globalization developed above (table 3).

As noted, one of the criticisms of the KFP index involves the often sharp change in ranking of countries from one year to the next. To test whether this might affect our results a similar discriminate excersise was performed on the KFP index for 2005 (actual country values for the year 2003). Again, all the MENA countries, together with Israel and Turkey were classified correctly with a high degree of probability (table 8). As before several governance variables, rule of law and voice/accountability differentiated the high from low globalized countries characterized the high.

These results suggest that given the KFP globalization rankings and country reform efforts in the governance and economic freedom areas, it should be possible to assess ${ }^{10}$ the extent to which globalization is linked to the progress 
Table 6. Relative globalization - overall globalization ranking

\begin{tabular}{|c|c|c|c|c|c|c|}
\hline & Voice & $\begin{array}{l}\text { Political } \\
\text { stability }\end{array}$ & $\begin{array}{l}\text { Government } \\
\text { effectiveness }\end{array}$ & $\begin{array}{c}\text { Regulatory } \\
\text { quality }\end{array}$ & $\begin{array}{c}\text { Rule of } \\
\text { law }\end{array}$ & $\begin{array}{l}\text { Control of } \\
\text { corruption }\end{array}$ \\
\hline \multicolumn{7}{|c|}{ Globalization ranking - bottom group (31 countries) } \\
\hline Mean & -0.22898 & -0.35825 & -0.08878 & -0.03460 & -0.20147 & -0.29696 \\
\hline \multicolumn{7}{|c|}{ Globalization ranking - top group (31 countries) } \\
\hline Mean & 1.14075 & 1.02967 & 1.35348 & 1.22553 & 1.36119 & 1.41018 \\
\hline \multirow[t]{2}{*}{ Difference } & 1.36973 & 1.38792 & 1.44226 & 1.26013 & 1.56266 & 1.70714 \\
\hline & $\begin{array}{l}\text { Trade } \\
\text { policy }\end{array}$ & $\begin{array}{c}\text { Fiscal } \\
\text { burden }\end{array}$ & $\begin{array}{l}\text { Government } \\
\text { intervention }\end{array}$ & $\begin{array}{l}\text { Monetary } \\
\text { policy }\end{array}$ & $\begin{array}{c}\text { Foreign } \\
\text { investment }\end{array}$ & \\
\hline \multicolumn{7}{|c|}{ Globalization ranking - bottom group (31 countries) } \\
\hline Mean & 3.67 & 3.34 & 2.76 & 2.62 & 2.85 & \\
\hline \multicolumn{7}{|c|}{ Globalization ranking - top group (31 countries) } \\
\hline Mean & 2.23 & 4.00 & 2.51 & 1.56 & 2.12 & \\
\hline \multirow[t]{2}{*}{ Difference } & -1.44 & -0.66 & -0.25 & -1.06 & -0.73 & \\
\hline & $\begin{array}{l}\text { Banking \& } \\
\text { finance }\end{array}$ & $\begin{array}{l}\text { Wages \& } \\
\text { prices }\end{array}$ & $\begin{array}{l}\text { Property } \\
\text { rights }\end{array}$ & Regulation & $\begin{array}{l}\text { Informal } \\
\text { cmarket }\end{array}$ & \\
\hline \multicolumn{7}{|c|}{ Globalization ranking - bottom group (31 countries) } \\
\hline Mean & 3.22 & 2.61 & 3.19 & 3.54 & 3.60 & \\
\hline \multicolumn{7}{|c|}{ Globalization ranking - top group (31 countries) } \\
\hline Mean & 2.08 & 2.24 & 1.73 & 2.65 & 1.94 & \\
\hline Difference & -1.14 & -0.37 & -1.46 & -0.89 & -1.66 & \\
\hline
\end{tabular}

Source: Compiled by author. 
Table 7. Globalization groupings 2002

\begin{tabular}{|c|c|c|c|}
\hline Country & $\begin{array}{l}\text { Determinant } \\
\text { score }\end{array}$ & $\begin{array}{l}\text { Probability } \\
\text { low }\end{array}$ & $\begin{array}{l}\text { Globalization } \\
\text { high }\end{array}$ \\
\hline \multicolumn{4}{|c|}{ Using Kearney Overall Rank } \\
\hline Morocco & -0.07366 & 0.59651 & 0.40349 \\
\hline Tunisia & -0.86952 & 0.94749 & 0.05251 \\
\hline Egypt & -1.94019 & 0.99809 & 0.00191 \\
\hline Pakistan & -2.72574 & 0.99984 & 0.00016 \\
\hline Saudi Arabia & -1.49085 & 0.99220 & 0.00780 \\
\hline Iran & -1.62718 & 0.99491 & 0.00509 \\
\hline Israel & 0.82267 & 0.08116 & 0.91884 \\
\hline Turkey & -2.04616 & 0.99863 & 0.00137 \\
\hline \multicolumn{4}{|c|}{$\begin{array}{l}\text { Initial grouping: High Globalization Group Kearney rank 1-31, } \\
\text { Low Globalization Group, Kearney rank 32-62. }\end{array}$} \\
\hline \multicolumn{4}{|c|}{$\begin{array}{l}\text { Discriminating variables (1) rule of law, (2) voice and accountability, } \\
\text { (3) property rights and (4) regulatory quality. }\end{array}$} \\
\hline \multicolumn{4}{|c|}{ Probability of correct placement $91.9 \%$} \\
\hline \multicolumn{4}{|c|}{ Using Factor 1 Score Ranking } \\
\hline Morocco & -0.60916 & 0.82544 & 0.17456 \\
\hline Tunisia & -0.34861 & 0.69782 & 0.30218 \\
\hline Egypt & -0.71304 & 0.86288 & 0.13712 \\
\hline Pakistan & -2.10220 & 0.99653 & 0.00347 \\
\hline Saudi Arabia & -0.07323 & 0.51984 & 0.48016 \\
\hline Iran & -1.84455 & 0.99298 & 0.00702 \\
\hline Israel & 0.75541 & 0.09974 & 0.90026 \\
\hline Turkey & -0.92794 & 0.91913 & 0.08087 \\
\hline \multicolumn{4}{|c|}{$\begin{array}{l}\text { Initial grouping: High Globalization Group, Factor } 1 \text { Score equal or } \\
\text { greater than } 0 \text {, Low Globalization Group, factor } 1 \text { Score less than } 0 .\end{array}$} \\
\hline \multicolumn{4}{|c|}{ Discriminating variables: (1) rule of law. } \\
\hline \multicolumn{4}{|c|}{ Probability of correct placement $91.9 \%$} \\
\hline
\end{tabular}

Source: Compiled by author.

made in a country's liberalization efforts. Put differently, which reforms or interaction of reforms drive globalization in general and in the MENA region in particular? ${ }^{11}$

The results of this assessment produced some interesting findings (figure 2). First, governance measures dominated the country grouping structure best describing the KFP overall globalization ranking. Specifically, based on progress made in improving the rule of law, countries can be grouped ${ }^{12}$ into three distinct categories: (1) a low rule of law grouping of 31 countries with a mean globalization score of 45.8, (2) a medium attainment rule of law grouping of 19 countries with a mean globalization score 22.6, and (3) a final group of 12 countries at the high-end of the rule of law scale. This group's mean ranking on the KFP globalization scale was 8.5.

Second, for the bottom two clusters of countries, an additional statistically significant split exists. This split is controlled by progress made in an average of the six measures of governance. For the 31 low rule of law countries, this split produces two more distinct sets of countries -25 countries with low overall 
Table 8. Globalization Groupings 2003

\begin{tabular}{|c|c|c|c|}
\hline Country & $\begin{array}{l}\text { Descriminant } \\
\text { score }\end{array}$ & $\begin{array}{l}\text { Probability } \\
\text { low }\end{array}$ & $\begin{array}{l}\text { Globalization } \\
\text { high }\end{array}$ \\
\hline \multicolumn{4}{|c|}{ Using Kearney Overall Rank } \\
\hline Morocco & -0.51437 & 0.82937 & 0.17063 \\
\hline Tunisia & -1.07823 & 0.95983 & 0.04017 \\
\hline Egypt & -1.52668 & 0.98834 & 0.01166 \\
\hline Pakistan & -2.63047 & 0.99948 & 0.00052 \\
\hline Saudi Arabia & -1.31911 & 0.97924 & 0.02076 \\
\hline Iran & -1.16503 & 0.96828 & 0.03172 \\
\hline Israel & 0.72710 & 0.12734 & 0.87266 \\
\hline Turkey & -1.79501 & 0.99450 & 0.00550 \\
\hline \multicolumn{4}{|c|}{$\begin{array}{l}\text { Initial grouping: High Globalization Group Kearney rank 1-31, } \\
\text { Low Globalization Group, Kearney rank 32-62. }\end{array}$} \\
\hline \multicolumn{4}{|c|}{$\begin{array}{l}\text { Discriminating variables (1) rule of law, (2) voice and accountability, } \\
\text { and (3) property rights. }\end{array}$} \\
\hline Probability of & & & \\
\hline \multicolumn{4}{|c|}{ Using Factor 1 Score Ranking } \\
\hline Morocco & -0.59353 & 0.85785 & 0.14215 \\
\hline Tunisia & -0.33966 & 0.75499 & 0.24501 \\
\hline Egypt & -0.69475 & 0.88750 & 0.11250 \\
\hline Pakistan & -2.04826 & 0.99649 & 0.00351 \\
\hline Saudi Arabia & -0.07135 & 0.60229 & 0.39771 \\
\hline Iran & -1.79722 & 0.99320 & 0.00680 \\
\hline Israel & 0.73603 & 0.15154 & 0.84846 \\
\hline Turkey & -0.90413 & 0.93213 & 0.06787 \\
\hline \multicolumn{4}{|c|}{$\begin{array}{l}\text { Initial grouping: High Globalization Group, Factor } 1 \text { Score equal } \\
\text { or greater than 0, Low Globalization Group, factor } 1 \text { Score less than } 0 .\end{array}$} \\
\hline \multicolumn{4}{|c|}{ Discriminating variables: (1) rule of law. } \\
\hline \multicolumn{4}{|c|}{ Probability of correct placement $91.9 \%$} \\
\hline
\end{tabular}

Source: Compiled by author.

governance and six countries with a moderate level of governance. The first group contains six Middle East (and Pakistan) countries, Morocco, Egypt, Turkey, Saudi Arabia and Iran. These countries clearly are at the lower end of the governance scale with their globalization prospects held back by the lack of progress in this area. Tunisia's governance efforts have paid off somewhat placing that country in the next set of countries. Finally, Israel with the highest level of governance and globalization in the region is classified along with 12 other countries in the medium rule of law, good overall governance grouping. This group has a mean globalization score of 26.8 .

As noted earlier, causation is always an issue in discussions of globalization. In this case is it possible to argue that improved levels of globalization (however attained) placed pressure on governments to improve their rule of law in order to remain competitive in the world economy? Or is the relationship from mainly from one of improved rule of law facilitating a higher level of globalization? 


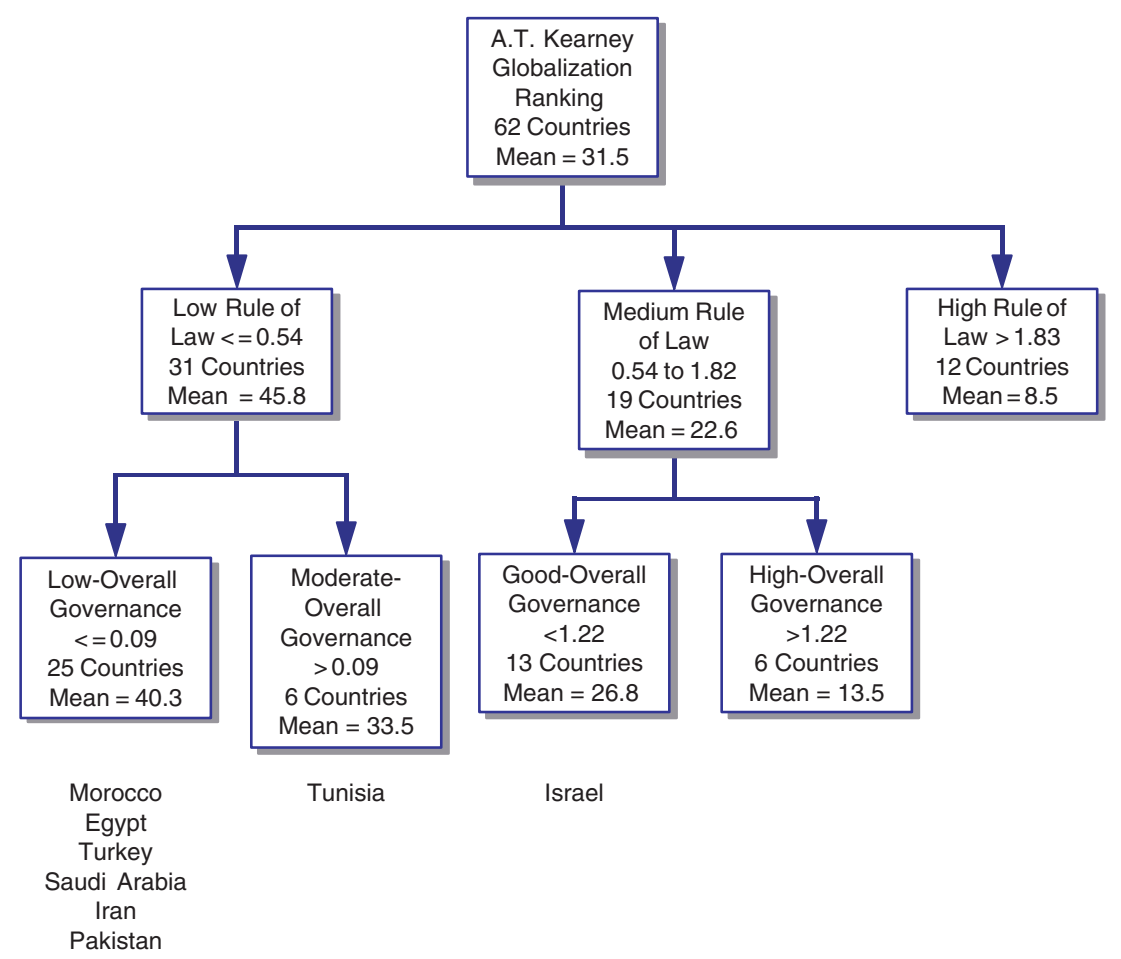

Figure 2. Factors affecting the Kearney/foreign policy globalization ranking (Source: Compiled by author)

To test the manner in which globalization and the rule of law impact each other a similar classification tree exercise was performed with the rule of law assumed to be determined by globalization. The other five governance measures and the 10 economic freedom measures were included as possible determinants of the rule of law. The results (figure 3) suggest that improvements in the rule of law are largely controlled by corruption and not globalization. As control of corruption improves, there tends to be is a corresponding gain in the rule of law-globalization does not appear to place an independent set of pressures on countries to revamp their legal systems. From this, we can tentatively conclude that improved governance, in this case through the rule of law, provides support for increased degrees of globalization.

\section{The General Globalization Index}

To see if the general globalization index derived (table 3) from the Kearney/ Foreign policy rankings paints an analogous picture, a similar classification analysis was performed on the index presented in table 4. The results (figure 4) are of the same rough order of magnitude as was the case with the 


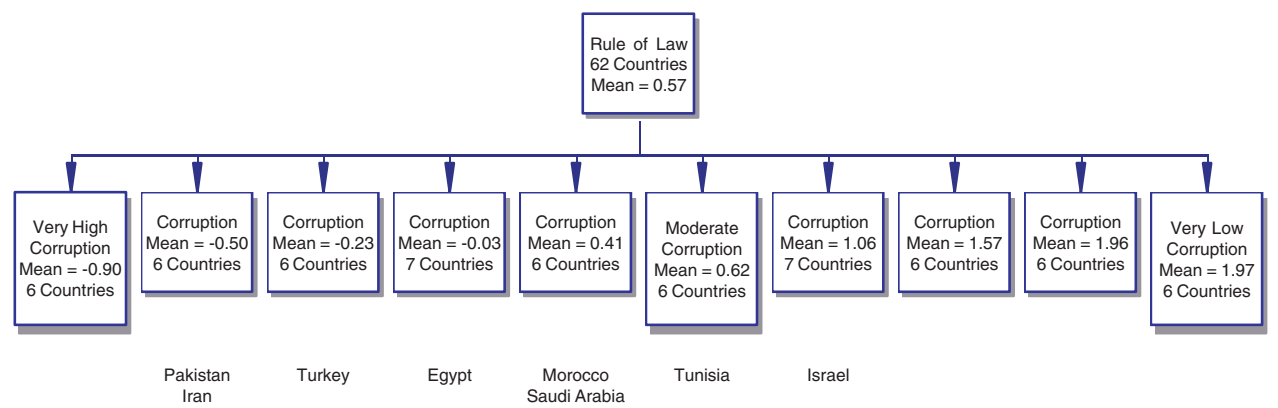

Figure 3. Factors affecting the rule of law index (Source: Compiled by author) 


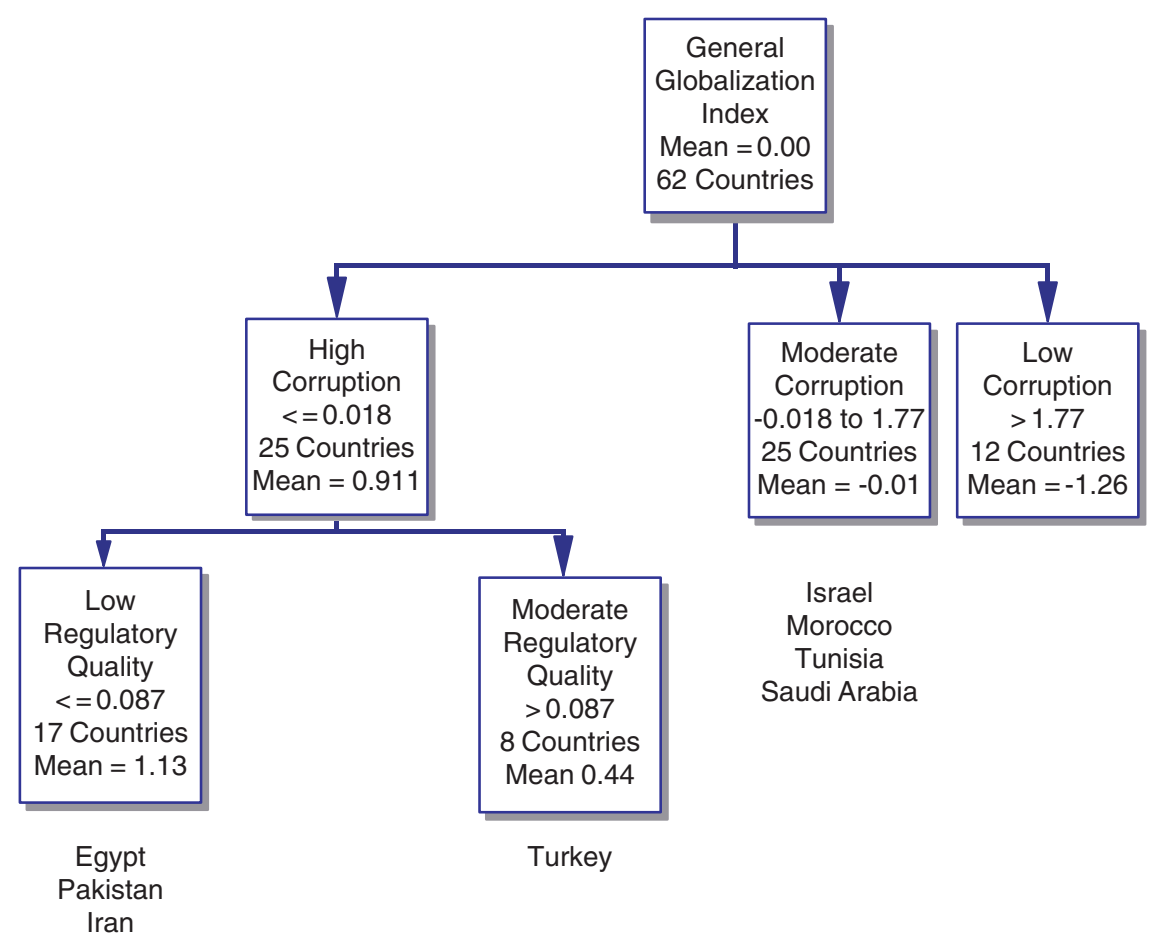

Figure 4. Factors affecting the general globalization index (Source: Compiled by author)

A.T. Kearney/Foreign Policy index. Again, governance reforms dominate the structure of relationships, with corruption entering directly (rather than through the rule of law as with the Kearney/Foreign Policy index) to partition the globalization index into three groups of countries.

As expected, a country's globalization ranking improves with improved control over corruption. Countries with high levels of corruption can offset this impediment somewhat through improving their regulatory quality as in the case of Turkey. Clearly though, a more efficient strategy is to face corruption directly as in the case of Israel, Morocco, Tunisia and Saudi Arabia. Finally causation likely runs directly from corruption to globalization (higher negative means in figure 4 represent higher ranks on the general globalization index).

The results from the analysis of the general globalization index suggest that the KFP rankings in the sub categories of technology, economic globalization, personal globalization, and political globalization are likely to be robust enough to warrant further analysis.

\section{The KFP Globalization Sub-Components}

In the case of technological globalization (figure 5), economic variables enter for the first time. Countries fall into groups of ascending technological 


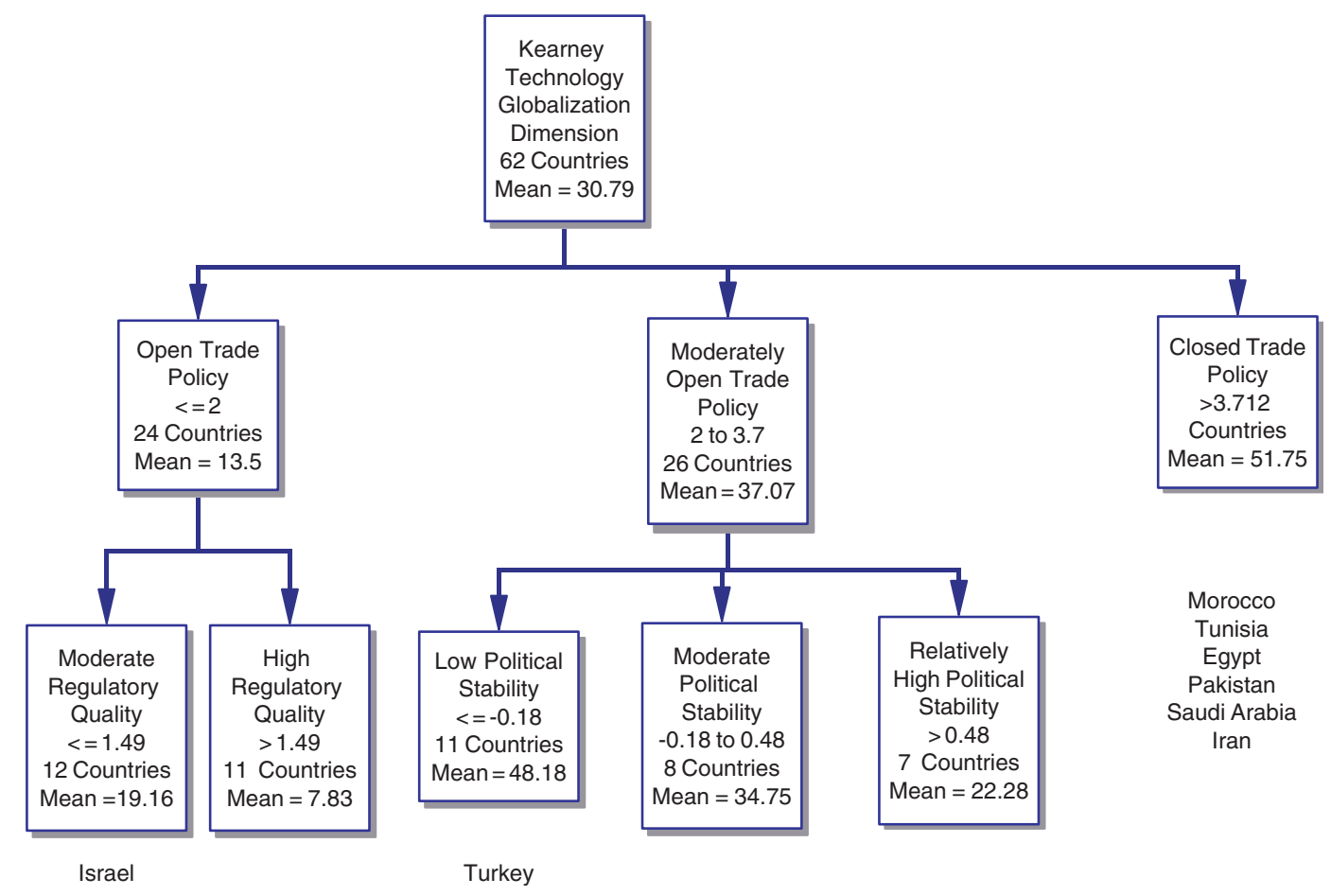

Figure 5. Factors affecting the Kearney globalization/technology index (Source: Compiled by author) 
globalization depending on the extent to which they formulate an open trade policy. Specifically, the 24 countries with a very open trade policy have a mean technological globalization ranking of 13.5, whereas the bottom 12 countries in terms of trade openness have a mean ranking of 51.75 (with 62 the lowest rank).

Those countries at the top of the trade policy scale have improved their technological globalization ranking even further through the establishment of a high quality regulatory environment. Of the Middle Eastern countries in our sample, only Israel appears in a position to increase through improved regulation of its regulatory environment. Turkey on the other hand falls in an intermediate trade-openness group. The country's low mean score on the technological globalization index is due to its trade policies, but within that context, could be improved somewhat through improved political stability.

Unfortunately most of our sample MENA countries fall in the bottom category because of their relatively closed economies. ${ }^{13}$ If these countries want to get linked in with the flow of world-wide technological information, they must place concerted efforts into opening their economies through improved trade policy. As noted above, given the fact that several of these countries are not even members of the World Trade Organization, it may take some years before significant progress is made in the technological area.

The KFP Economic Globalization rankings are controlled by political stability with three main clusters of countries partitioning the rankings (figure 6). A further split of the least globalized group (mean ranking of 45.2 out of 62) can be made on the basis of the extent of the black market or informal economy. Those countries with large informal economies (Pakistan and Iran) have globalization rankings considerably below those countries (Israel, Morocco, Egypt and Turkey) where the black market is not as prevalent. Again governance measures dominate the country grouping process. Still, this result is somewhat surprising in the sense that only one of the economic freedom variables (tangentially at that) helps tp explain the relative ranking of countries along the economic dimension.

Government effectiveness is the most significant factor clustering countries along the personal globalization dimension (figure 7). In contrast to several of the previous globalization dimensions, the Middle Eastern countries are fairly spread out along the personal globalization scale, with Turkey, Pakistan and Iran in the bottom group of countries, while Israel and Tunisia are in a group of 19 countries just below the top group.

Finally, the main split in the political globalization scale of countries is formed by the voice-accountability measure of governance (figure 8). Two groups of countries are present, a fairly large group of 37 countries with relatively high deficiencies in voice and accountability and a higher group of 15 countries with a mean political globalization ranking of 16 . All of the Middle Eastern countries fall in the low group. While countries in the high group appear to have the option of increasing their globalization along this dimension through improved trade openness, the Middle Eastern countries will have to place most of their efforts into improved voice governance before this option becomes available. 


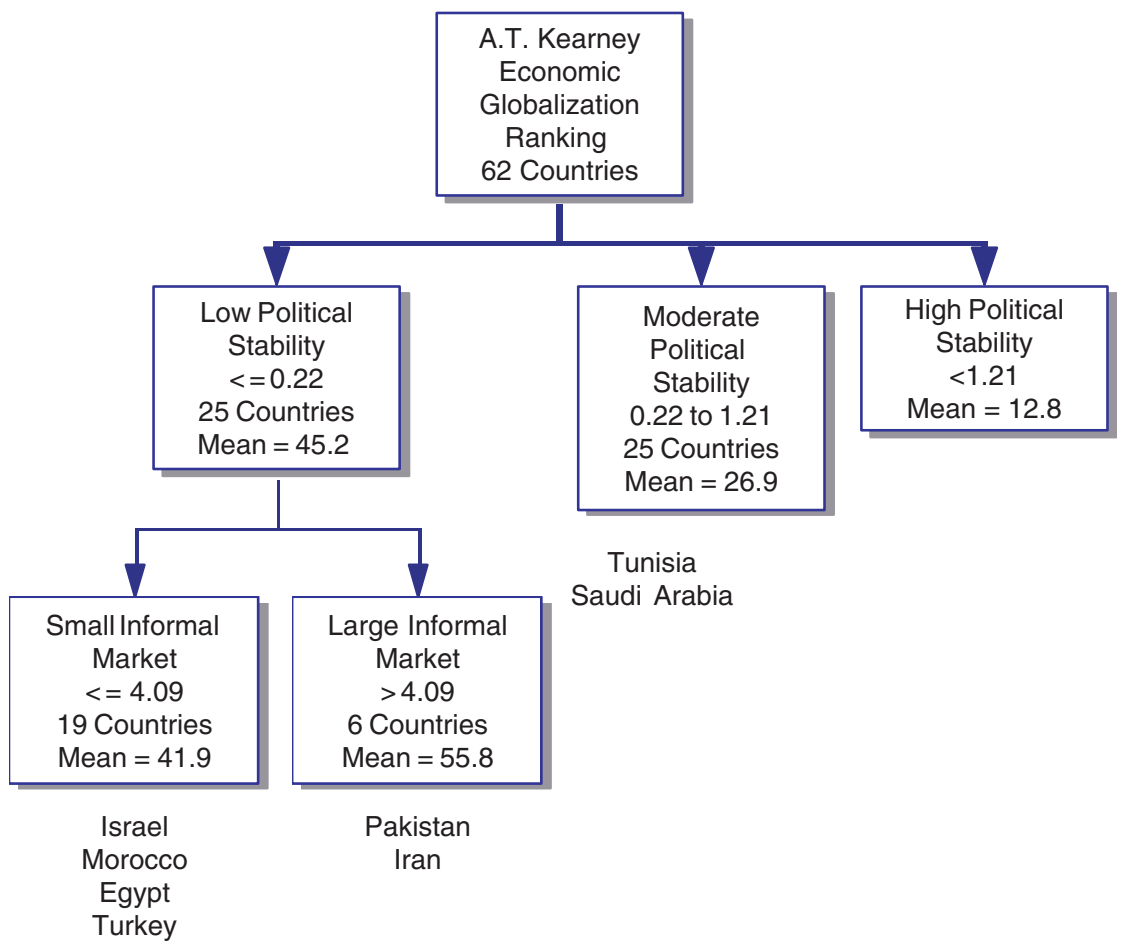

Figure 6. Factors affecting the Kearney economic globalization index (Source: Compiled by author)

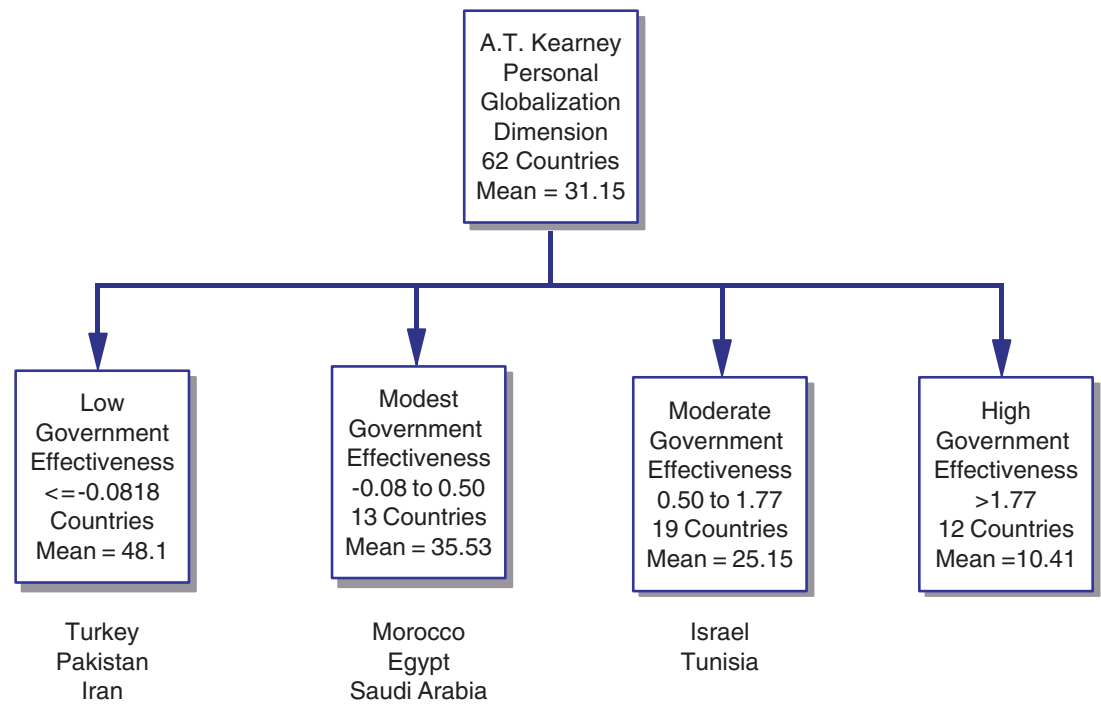

Figure 7. Factors affecting the Kearney personal globalization index 


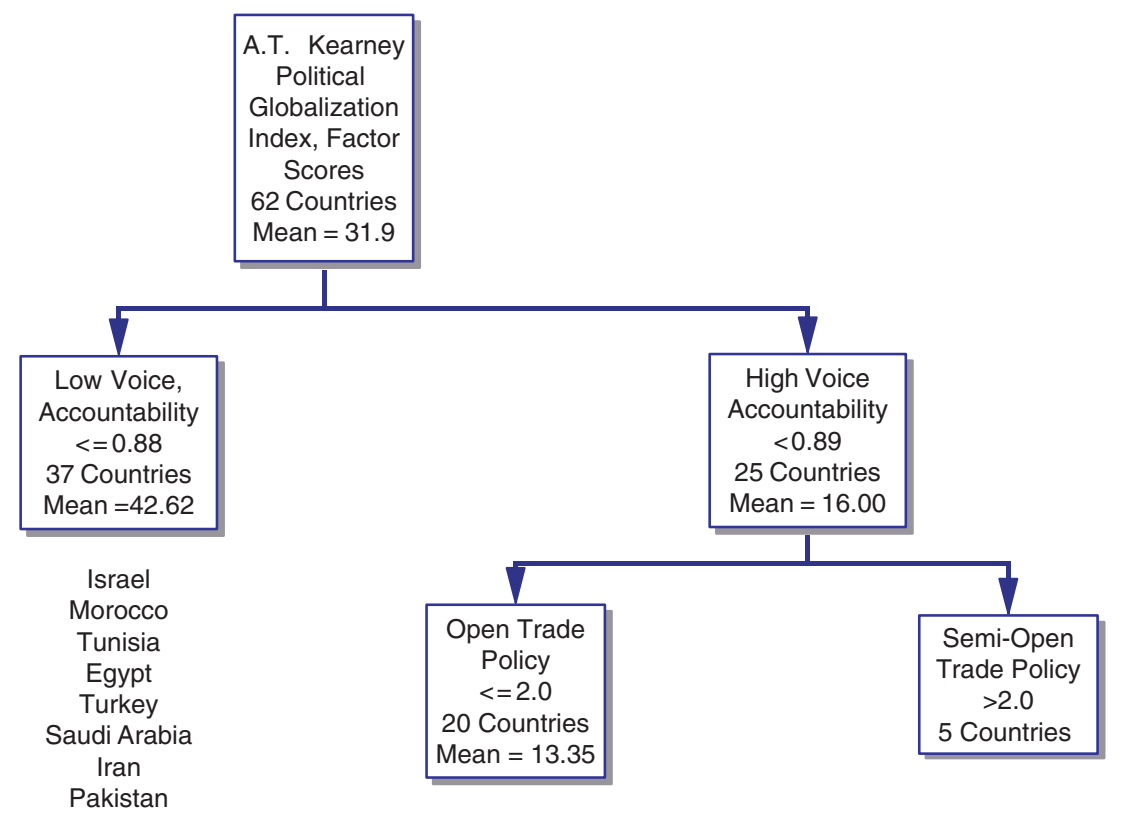

Figure 8. Factors affecting the Kearney political globalization index (Source: Compiled by author)

\section{Conclusions}

As noted in the widely discussed Arab Human Development Report (United Nations, 2002) the MENA region performs poorly in the areas of civil and political freedoms, gender equality, and more generally opportunities for the full development of human capabilities and knowledge. To overcome the handicaps, modern institutions such as freely elected legislature and competent and independent judiciaries and institutions that safeguard civil and human rights need to be strengthened.

As many studies have shown, economic growth and good governance are interconnected. In most regions, as incomes grow so then does public governance. However, in the MENA region, the quality of public accountability did not follow this pattern (World Bank, 2004). As noted above, the region lags considerably behind other parts of the world in all of the major dimensions of governance.

Productivity, economic growth and good governance are related and given the lack of improvements in governance, the MENA economies have suffered (World Bank, 2004). Productivity in the MENA region has been on a decline for 30 years and average annual per capita growth has grown at only $0.9 \%$ over the last 20 years. Clearly, excessive bureaucratic systems and lengthy regulatory environments inhibit growth.

The analysis above suggests increased levels of globalization are a related benefit to the MENA region to be derived from improved governance. For the 
Middle East countries wishing to improve their integration into the world economy, improvements in the various areas of governance have the greatest pay-offs at the present time. While economic reforms have been carried out in many of the MENA countries, our analysis suggests further continuation in this area, while desirable from a number of perspectives, would seem to hold out little prospect for significantly improving the integration of these countries into the global economy.

The task of making significant improvement in governance is enormous, however, facing considerable resistance throughout the region. In part, some of this resistance may stem from the fact that there is a sizeable imbalance in the way the region has preceded with liberalization. Much more progress in recent years has been made in the economic freedom area relative to the various dimensions of governance. No doubt this has resulted in many of the key countries being exposed to some of the competitive rigors of international competition, while at the same time not possessing the domestic institutions capable of enabling the countries to take advantage of opportunities opened up by increased integration into the world economy. This has resulted in a negative perception of globalization throughout most of the region, making progress in the governance area all that more difficult.

\section{Notes}

1. Cf. Sachs (2000) for an elaboration on globalization's impact on growth.

2. As developed in A.T. Kearney (2002).

3. A full critique of the index is given in Lockwood (2004).

4. For an extensive discussion on factor analysis see Rummel (1970).

5. See for example Lopez-Carlos (2005).

6. See for example Miles et al. (2004).

7. Available from: Global Economic Software, Ltd, www.globaleconomicsoftware.com. Cf. Looney (2003) for an application of this data set to the Middle East.

8. The MENA countries included are Morocco, Tunisia, Egypt, Pakistan, Saudi Arabia and Iran. In addition two regional countries Israel and Turkey not normally grouped as MENA nations were included.

9. For a description of this technique and interpretation of results see SPSS Base 10.0 (SPSS, 1999).

10. For this purpose a classification tree was developed. See SPSS (2001) for a description of the program and logic underlying classification trees.

11. The predictive variables were the six governance measures and ten economic freedom indices) listed in table 5 , as well as an overall average of the governance variables and the economic freedom measures. The reforms are averaged over the 2000-2002 period and the Kearney globalization rankings are for the year 2002 (the latest year available).

12. A good discussion of how groups are formed is given in Breiman et al. (1984).

13. One has to assume most of the MENA countries not included in the KFP index are likely to be even less integrated into the world economy.

\section{References}

Abed, G. T. (2003) Unfulfilled promise. Finance \& Development, 40(1), pp.

Andersen, T., Andersen, M. and Herbertsson, T. T. (2003) Measuring Globalization. Discussion Paper 817 (Bonn: IZA).

Bergsten, F. (2004) The G-20 and the world economy. World Economics, 5(3), pp. 28-29. 
Breiman, L. et al. (1984) Classification and Regression Trees (Pacific Grove, CA: Wadsworth).

Dunn, R. (2001) Has the U.S. economy really been globalized? Washington Quarterly, 24(1), pp. 53-64.

Eiras, A. I. (2003) Ethics, Corruption and Economic Freedom (Washington, DC: Heritage Foundation).

Griswald, D. (2000) The blessings and challenges of globalization. International Journal of World Peace, 17(3), प-U.

Henderson, D. (1999) The changing international economic order, rival visions for the coming millennium (Melborne: Melborne Business School).

Intriligator, M. D. (2003) Globalization. The Milken Review, प-M.

Kamarva, M. (2004) Structural impediments to economic globalization in the Middle East. Middle East Policy, I, pp. 96-112.

Kaufman, D., Kraay, A. and Mastruzzi, M. (2003) Governance Matters III: Governance Indicators for pp. 1996-2002 (Washington: World Bank).

Kearney, A. T. (2002) Measuring globalization. Foreign Policy, 122.

Kearney, A. T. (2004) Measuring globalization. Foreign Policy, 141.

Kearney, A. T. (2005) Measuring globalization. Foreign Policy, 148.

Kitschelt, H. (2004) A review of the political economy of governance. World Bank Policy Research Working Paper 3315, Washington, DC.

Landes, D. (1998) The Wealth and Poverty of Nations: Why Some are so Rich and Some so Poor (New York: Norton).

Lockwood, B. (2004) How robust is the Kearney/Foreign Policy Index? The World Economy, 27(4), pp. $507-524$.

Looney, R. and Frederiksen, P. C. (2004) An assessment of relative globalization in Asia during the 1980s and 1990s. Journal of Asian Economics, 15(2), pp. 267-286.

Looney, R. (2003) Iraq's economic transition: the neoliberal model and its role. The Middle East Journal, 57(4), pp. 568-587.

Lopez-Carlos, A. (2005) Executive summary, in A. Lopez-Carlos and K. Schwab, The Arab World Competitiveness Report 2005, pp. 3-10 (New York: Palgrave).

Lucas, R. (1988) On the mechanics of economic development. Journal of Monetary Economics, 22, pp. 3-42.

Miles, M., Feulner, E., O'Grady, M. A. and Eiras, A. (2004) 2004 Index of Economic Freedom (Washington, DC: Heritage Foundation).

Mujahid, S. (2002) WTO, globalization and Pakistan: dreaming for global living standards. Pakistan and Gulf Economist, I, pp. M-U.

Noland, M. and Pack, H. (2004) The Economics of the Middle East in an Era of Globalization (Washington, DC: Institute for International Economics).

Nunnenkamp, P. (2004) Why economic growth has been weak in Arab countries: the role of exogenous shocks, economic policy failure and institutional deficiencies, Kiel Discussion Papers 409.

Romer, P. (1986) Increasing returns and long run growth. Journal of Political Economy, 94, pp. $1002-1037$.

Rummel, R. (1970) Applied Factor Analysis (Evanston: Northwestern University Press).

Sachs, J. (2000) Globalization and patterns of economic development. Weltwirtschaftliches Archiv, 136(4), pp. 579-600.

Sen, A. K. (2001) If it's fair, it's good. International Herald Tribune, 14 July.

SPSS AnswerTree 3.0 User's Guide (2001) (Chicago: SPSS).

SPSS Base 10.0 (1999) (Chicago: SPSS).

World Bank (1996) Global Economic Prospects of the Developing Countries (Washington, DC: World Bank).

World Bank (2001) Globalization Growth and Poverty: Building an Inclusive World Economy (Washington, DC: World Bank).

World Bank (2004) Better Governance for Development in the Middle East and North Africa (Washington, DC: World Bank). 